\title{
Rhodanese from Thiobacillus A2: Catalysis of Reactions of Thiosulphate with Dihydrolipoate and Dihydrolipoamide
}

\author{
By MARVIN SILVER* AND D. P. KELLY \\ Department of Environmental Sciences, University of Warwick, Coventry $\mathrm{CV}_{4} 7 \mathrm{AL}$
}

(Received 12 April 1976; revised 6 August 1976)

SUMMARY

Rhodanese (thiosulphate: cyanide sulphurtransferase EC. 2.8. I. I) was purified 25- to 30-fold from thiosulphate-grown Thiobacillus A2. It exhibited a pH optimum between pH 10.2 and 10.4 and apparent $K_{\mathrm{m}}$ values of $0.36 \mathrm{mM}-\mathrm{Na}_{2} \mathrm{~S}_{2} \mathrm{O}_{3}$ and $17 \mathrm{~mm}-$ $\mathrm{KCN}$. Ultraviolet spectrophotometry and thin-layer chromatography showed that the enzyme catalysed the reaction of $\mathrm{S}_{2} \mathrm{O}_{3}{ }^{2-}$ with dihydrolipoic acid or dihydrolipoamide, producing $\alpha$-lipoate or lipoamide, with the intermediate production of the persulphides of dihydrolipoate and dihydrolipoamide, which were demonstrated chromatographically. This is the first demonstration of catalysis by a thiobacillus rhodanese of reactions which are likely to be physiologically important in the oxidative dissimilation of thiosulphate by a central energy-conserving pathway.

\section{INTRODUCTION}

Rhodanese (thiosulphate:cyanide sulphurtransferase EC. 2.8.1.I) is found in diverse tissues and organisms and probably acts as a general sulphur transferase (Westley, 1973; Sörbo, 1975). It occurs in many thiosulphate-oxidizing bacteria (Charles \& Suzuki, 1966; Yoch \& Lindstrom, 1971; Guay \& Silver, I975; Kelly \& Tuovinen, 1975; Sörbo, 1975).

Most thiobacilli can obtain energy for growth by oxidizing thiosulphate. Although the mechanism for thiosulphate oxidation is still uncertain, the initial step is probably the cleavage of thiosulphate to sulphite and a sulphane moiety, which is transferred to an enzyme or enzyme cofactor (Kelly, 1968; Suzuki, 1975). Rhodanese has been suggested as the catalyst of this reaction (Tabita, Silver \& Lundgren, 1969; Sörbo, 1975; Suzuki, 1975). Cyanide can be used as an acceptor for the sulphane-sulphur atom, but the enzyme will act with various sulphur donor and acceptor compounds (Westley, 1973; Sörbo, 1975). There is little reliable evidence to suggest a universal role for cyanide as the acceptor substrate for the rhodanese enzyme in vivo, and the high $K_{\mathrm{m}}$ values (Kelly \& Tuovinen, 1975) indicate no physiological role for cyanide. Volini \& Westley (1966) showed that dihydrolipoate and dihydrolipoamide served as sulphur acceptors for beef rhodanese, with the intermediate formation of their respective persulphides, but no similar investigations have been carried out with a thiobacillus rhodanese, although Kelly (1972) suggested that dihydrolipoate might act as an alternative to cyanide in thiobacilli.

Thiobacillus A2, grown on thiosulphate, contains only very low levels of 'thiosulphateoxidizing enzyme' (Kelly, 1973; Kelly \& Tuovinen, 1975) and adenylylsulphate (APS) reductase (Aleem, 1975; Silver \& Kelly, unpublished), but has significant rhodanese activity in crude extracts. Enzyme activity in crude preparations was optimum at $\mathrm{pH} I \mathrm{I} \cdot 3$, which is

\footnotetext{
* Permanent address: Département de Biochimie, Faculté des Sciences et de Génie, Université Laval, Québec GIK 7P4, Canada.
} 
2 to $3 \mathrm{pH}$ units more alkaline than the optimum for the enzyme from other thiobacilli (Bowen, Butler \& Happold, I965; Tabita et al., 1969; Kelly \& Tuovinen, 1975).

We report properties of a purified rhodanese and show its catalysis of sulphane-sulphur transfer from thiosulphate not only to cyanide but to dihydrolipoate or dihydrolipoamide with the intermediate formation of their respective persulphides, thus indicating a truly physiological role for the enzyme in this thiobacillus.

\section{METHODS}

Culture of the organism and preparation of extracts. Thiobacillus A2 was grown at $30^{\circ} \mathrm{C}$ on $0.5 \%(\mathrm{w} / \mathrm{v}) \mathrm{S}_{2} \mathrm{O}_{3}{ }^{2-}$, formate or sucrose, harvested and washed as described previously (Kelly \& Tuovinen, 1975). All subsequent procedures were carried out at o to $4{ }^{\circ} \mathrm{C}$. After washing with $0 . \mathrm{I} \mathrm{M}$-Tris/ $\mathrm{HCl}\left(\mathrm{pH} \mathrm{8.5)}\right.$, the cells $\left(0.1\right.$ to $0.2 \mathrm{~g}^{2}$ wet $\left.\mathrm{wt} \mathrm{ml}^{-1}\right)$ were suspended in $0 . \mathrm{I} \mathrm{M}$ Tris/ $\mathrm{HCl}\left(\mathrm{pH} \mathrm{8.5)}\right.$ containing $\mathrm{IO}^{-3} \mathrm{M}^{-\mathrm{S}_{2}} \mathrm{O}_{3}{ }^{2-}$, and broken by passage three times through a French pressure cell at $1.4 \times 10^{8} \mathrm{~Pa}\left(20000 \mathrm{lbf} \mathrm{in}^{-2}\right)$ in the presence of RNAase and DNAase (each at $2 \mu \mathrm{g} \mathrm{ml}^{-1}$ ). The extracts were clarified by centrifuging at $100000 \mathrm{~g}$ for $\mathrm{I} \mathrm{h}$ and used either for crude extract assays or for purification of the rhodanese enzyme.

Enzyme purification. Rhodanese was partially purified from thiosulphate-grown Thiobacillus A2 by a procedure similar to that previously described (Tabita et al., 1969). The crude extract was adjusted to $\mathrm{pH} 5^{\circ} \mathrm{O}$ with $\mathrm{I}$ M-acetic acid, stirred in an ice bath for $30 \mathrm{~min}$, then centrifuged at $13000 \mathrm{~g}$ for $20 \mathrm{~min}$. $\left(\mathrm{NH}_{4}\right)_{2} \mathrm{SO}_{4}$ fractionation between 25 and $90 \%$ saturation at $\mathrm{pH} 5^{\circ} \mathrm{O}$ was followed by overnight dialysis against 200 vols $0.0 \mathrm{I} \mathrm{M}-\mathrm{Tris} / \mathrm{HCl}$ (pH 8.5) containing $10^{-3} \mathrm{M}_{-} \mathrm{S}_{2} \mathrm{O}_{3}{ }^{2-}$. Dialysis was repeated against fresh buffer for $3 \mathrm{~h}$ and then the enzyme solution, containing Io to $15 \mu \mathrm{g}$ protein $\mathrm{ml}^{-1}$, was treated with an equal volume of a $20 \%$ slurry of DEAE-cellulose. The cellulose with the enzyme adsorbed was recovered by centrifuging at $13000 \mathrm{~g}$ for $20 \mathrm{~min}$ and washed successively with five concentra-

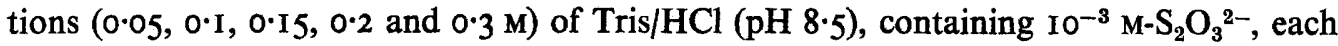
equal to the original volume of the crude extract. Almost all the activity was recovered when the cellulose was eluted with the highest concentration of buffer.

Protein was estimated according to the procedure of Lowry et al. (195I) using crystalline bovine serum albumin as standard.

Enzyme assays. Rhodanese activity was measured routinely by a modification of the method of Tabita et al. (1969). Reaction mixtures, in screw-cap test tubes, contained, unless otherwise specified: $500 \mu$ mol unadjusted Tris (pH 10.6); $50 \mu \mathrm{mol} \mathrm{Na} \mathrm{N}_{2} \mathrm{~S}_{3} ; 50 \mu \mathrm{mol} \mathrm{KCN}$ ( $\mathrm{pH} 10.4$ ); enzyme (usually $0.05 \mathrm{ml}$ ); and water to give $5^{\circ} \mathrm{Oml}$. After incubation for $10 \mathrm{~min}$ at $25{ }^{\circ} \mathrm{C}$, thiocyanate was determined as described previously (Tabita et al., I969). Although Tris has little buffering capacity at the $\mathrm{pH}$ of the assay system, less than $0.2 \mathrm{pH}$ unit difference was detected during a typical reaction. In all cases, $500 \mu \mathrm{mol}$ buffer was used in the reaction mixtures, and the $\mathrm{pH}$ values of all combinations of the assay mixtures were measured both at the beginning and end of the reaction times.

When dihydrolipoate or dihydrolipoamide was used as acceptor for the outer sulphur atom of thiosulphate, a modification of the assay system of Volini \& Westley (I966) was used. The reaction mixture contained (in $\mathrm{I} \cdot 0$ or $2.5 \mathrm{ml}$ ): unadjusted Tris ( $\mathrm{pH} \mathrm{I0} \cdot 6$ ), $0 . \mathrm{I} \mathrm{M}$; dihydrolipoate or dihydrolipoamide, $0.0 \mathrm{I} \mathrm{M}$; and thiosulphate, $0.0 \mathrm{I} \mathrm{M}$, with which the reaction was routinely initiated. Each reaction was monitored by scanning the absorption spectrum between 270 and $450 \mathrm{~nm}$, usually every $15 \mathrm{~min}$, for $2 \mathrm{~h}$. The amounts of $\alpha$-lipoate or lipoamide formed were calculated assuming a molar extinction coefficient of $1501 \mathrm{~mol}^{-1}$ $\mathrm{cm}^{-1}$ (Nakamura \& Tamura, 1974.) 


\section{Table I. Purification procedure for rhodanese}

Activity was assayed at each step with $0.05 \mathrm{ml}$ of enzyme preparation in the standard reaction mixture (see Methods). Activity is defined as $\mu \mathrm{mol}$ thiocyanate formed per $\mathrm{ml}$ in $10 \mathrm{~min}$; specific activity is the activity per $\mathrm{mg}$ protein in the preparation.

\begin{tabular}{|c|c|c|c|c|c|c|c|}
\hline Fractionation step & $\begin{array}{l}\text { Vol. } \\
\text { (ml) }\end{array}$ & $\begin{array}{l}\text { Protein } \\
\left(\mathrm{mg} \mathrm{ml}^{-1}\right)\end{array}$ & Activity & $\begin{array}{l}\text { Total } \\
\text { activity }\end{array}$ & $\begin{array}{l}\text { Specific } \\
\text { activity }\end{array}$ & $\begin{array}{l}\text { Purification } \\
\text { factor }\end{array}$ & $\begin{array}{l}\text { Recovery } \\
(\%)\end{array}$ \\
\hline Crude extract & II $\cdot 5$ & II $\cdot 60$ & 15.4 & 177 & $1 \cdot 33$ & $I \cdot 0$ & 100 \\
\hline pH 5 supernatant & II $\cdot 0$ & $7 \cdot 00$ & 14.0 & I6I & $2 \cdot 00$ & $1 \cdot 5$ & 91 \\
\hline $\begin{array}{l}0-25 \%\left(\mathrm{NH}_{4}\right)_{2} \mathrm{SO}_{4} \text { supernatant } \\
25-90 \%\left(\mathrm{NH}_{4}\right)_{2} \mathrm{SO}_{4} \text { precipitate, }\end{array}$ & II.O & $4 \cdot 60$ & $12 \cdot 5$ & 150 & $2 \cdot 72$ & $2 \cdot \mathrm{I}$ & 85 \\
\hline $\begin{array}{l}\text { dialysed } \\
\text { DEAE-cellulose eluate }\end{array}$ & $13 \cdot 5$ & $2 \cdot 50$ & $9 \cdot 0$ & $124: 5$ & $3 \cdot 60$ & $2 \cdot 7$ & 70 \\
\hline$(0.2-0.3 \mathrm{M}$ buffer $)$ & 12.5 & 0.19 & $7 \cdot 2$ & 90 & $37 \cdot 90$ & $28 \cdot 5$ & $5 \mathrm{I}$ \\
\hline
\end{tabular}

Thin-layer chromatography. To determine whether the persulphides of dihydrolipoate or dihydrolipoamide were intermediate products of the reaction catalysed by rhodanese, 25 to $50 \mu \mathrm{l}$ of the spectrophotometric assay mixtures after reaction times of $2 \mathrm{~h}$ were applied to silica-gel sheets and developed in either solvent 7 , propan-I-ol/acetic acid/35\% (I8 M) ammonia ( $7: 3: 2$, by vol.), or solvent 8 , butan-I-ol/acetic acid/35\% (I8 M) ammonia (7:3:2, by vol.), described previously (Silver \& Kelly, 1976). Reference compounds were $\alpha$-lipoate, dihydrolipoate, lipoamide, dihydrolipoamide, and the persulphides of dihydrolipoate and dihydrolipoamide. Detection of all compounds was by exposure to $I_{2}$ vapour.

Materials. All reagents were of the highest purity available from commercial sources. Dihydrolipoate, $\alpha$-lipoate, lipoamide and Tris were purchased from Sigma. Lipoamide was reduced to dihydrolipoamide by the method of Reed et al. (1958). The persulphides of dihydrolipoate and dihydrolipoamide were prepared by allowing the aqueous solutions of these compounds to react individually with sulphide, each at a concentration of $0.0 \mathrm{I} M$, at room temperature for $3 \mathrm{~h}$ (Villarejo \& Westley, 1963). Whatman DE-52 DEAE-cellulose was used for the purification of rhodanese. Thin-layer chromatography was done on Merck aluminium sheets precoated with silica gel $60 \mathrm{~F}_{254}$ (layer thickness $0.2 \mathrm{~mm}$ ).

\section{RESULTS}

Activity of rhodanese from Thiobacillus a2 grown on different substrates. The specific activities of crude extracts with respect to rhodanese were I.28, 0.83 and I.2I $\mu$ mol thiocyanate formed in $10 \mathrm{~min}$ per $\mathrm{mg}$ protein from Thiobacillus A2 grown on sucrose, formate and thiosulphate respectively. Each figure given is the average of at least five determinations.

Purification of the enzyme. Relative purifications of 25- to 30-fold were achieved for rhodanese from Thiobacillus A2 grown on thiosulphate, with yields of around $50 \%$ (Table I). Although the most purified fraction was stable when frozen, $50 \%$ of the activity was lost in $4 \mathrm{~h}$ in the unfrozen state at 0 to $4{ }^{\circ} \mathrm{C}$. Higher temperatures resulted in more rapid loss of activity. Extracts were therefore stored frozen in small volumes $(0.5$ to $\mathrm{r} .0 \mathrm{ml})$ and used immediately after thawing. Thawed extracts were not refrozen for reuse.

Using $8 \mu \mathrm{g}$ of the most purified enzyme preparation in the standard reaction mixture, the reaction rate was linear for more than $20 \mathrm{~min}$. In the absence of enzyme $0.1 \mathrm{I} \mu \mathrm{mol}$ thiocyanate was formed in $10 \mathrm{~min}$; the reaction rate with respect to enzyme concentration was linear up to 30 to $35 \mu \mathrm{g}$ protein in the reaction mixture.

Effect of $\mathrm{pH}$ on enzyme activity. The $\mathrm{pH}$ optimum of rhodanese in the presence of phosphate, glycine/ $\mathrm{NaOH}$ or Tris buffers was $10 \cdot 2$ to $10 \cdot 4$ (Fig. I). 
Effect of substrate concentration on enzyme activity. Apparent $K_{\mathrm{m}}$ values for thiosulphate and cyanide were determined from double reciprocal plots (Lineweaver \& Burk, 1934) of velocity of the rhodanese-catalysed reaction $\left[(\mu \mathrm{mol} \mathrm{SCN}-\text { formed/10 } \mathrm{min})^{-1}\right]$ against concentrations of $\mathrm{S}_{2} \mathrm{O}_{3}{ }^{2-}$ or $\mathrm{CN}^{-}$[ $\left.\mathrm{mM}^{-1}\right]$. Using Io $\mathrm{CN}^{-}$concentrations (4 to $50 \mathrm{mM}$ ) and $18 \mathrm{~S}_{2} \mathrm{O}_{3}{ }^{2-}$ concentrations $(0.2$ to $10 \mathrm{mM})$, no deviation from linear reciprocal plots was obtained, indicating that no substrate inhibition occurred, and apparent $K_{\mathrm{m}}$ intercept values were $17 \mathrm{mM}^{-\mathrm{CN}^{-}}$and $0.36 \mathrm{mM}^{-} \mathrm{S}_{2} \mathrm{O}_{3}{ }^{2-}$.

Rhodanese reaction using dihydrolipoate and dihydrolipoamide as cosubstrates. The absorbance at 333 to $335 \mathrm{~nm}$ of a reaction mixture containing rhodanese, thiosulphate and dihydrolipoate increased with incubation time (Fig. 2), reflecting the progressive formation of $\alpha$-lipoate. Similar results were obtained when dihydrolipoamide was used as the substrate. After reaction times of $2 \mathrm{~h}$, in the presence of dihydrolipoate there was an increase in absorbance of 0.20 (corresponding to the formation of $3.3 \mu \mathrm{mol} \alpha$-lipoate), and in the presence of dihydrolipoamide, an increase of 0.30 (corresponding to $5.0 \mu \mathrm{mol}$ lipoamide). In both cases, absence of peak broadening or of a shift of the absorption maximum indicated insignificant formation of any polysulphur compounds with marked absorption properties at 350 to $400 \mathrm{~nm}$. The rates of the reactions were linear with respect to time for less than 30 $\mathrm{min}$, and linear with respect to the amount of protein present for up to approximately $2 \cdot 5 \mu \mathrm{g}$. The production of free sulphide in the reaction mixtures was indicated by its odour. In the absence of enzyme, there was a linear increase in absorbance of 0.06 in $2 \mathrm{~h}$ (indicating formation of $\mathrm{I} \cdot 0 \mu \mathrm{mol} \alpha$-lipoate or lipoamide), and in the absence of thiosulphate, an increase of 0.01 in $2 \mathrm{~h}$. Neither NAD nor NADP (at I mM) was reduced in the course of this reaction, as no additional absorbance at $340 \mathrm{~nm}$ was observed.

Thin-layer chromatographic identification of persulphide intermediates. Thin-layer chromatograms of the spectrophotometric rhodanese assay mixtures after reaction times of $2 \mathrm{~h}$, and of reference compounds (Fig. 3) showed that with solvent $7, \alpha$-lipoate and dihydrolipoate had $R_{F}$ values of 0.90 to 0.92 , lipoamide and dihydrolipoamide had $R_{F}$ values of 0.86 to 0.89 , and their persulphides had identical $R_{F}$ values of 0.59 to 0.60 . With solvent $8, \alpha$-lipoate and dihydrolipoate had $R_{F}$ values of 0.91 to 0.93 , lipoamide and dihydrolipoamide had $R_{F}$ values of 0.80 to $0.8 \mathrm{I}$, and both persulphides had $R_{F}$ values of $0.4 \mathrm{I}$ to 0.43 . When $25 \mu \mathrm{l}$ of each of the assay systems was examined by this method with solvent 7 , brown spots could be readily detected which had $R_{F}$ values of 0.92 and 0.59 when dihydrolipoate was used as substrate, and 0.89 and 0.59 when dihydrolipoamide was used. Similarly, with solvent $8, R_{F}$ values of $0.9 \mathrm{I}$ and $0.4 \mathrm{I}$ were observed when dihydrolipoate was used as substrate, and 0.80 and 0.43 when dihydrolipoamide was used. In all cases, when the sheet was exposed to iodine vapour, the spots of lower $R_{F}$ values remained lighter than the background for over $5 \mathrm{~min}$, turning darker on continued exposure, whereas the spots of higher $R_{F}$ values were always darker than the background (Silver \& Kelly, 1976).

\section{DISCUSSION}

Rhodanese occurs in all thiobacilli so far examined, but the evidence for its role in oxidative sulphur metabolism resides solely in the increase in specific activity observed after growth on thiosulphate (Lé John, Van Caeseele \& Lees, 1967; Taylor \& Hoare, 1969) or exposure to cyanide (Bowen et al., 1965). Like Taylor \& Hoare (1969), we found rhodanese activity in crude extracts to be increased when Thiobacillus A2 was grown on thiosulphate rather than formate, but, in contrast to earlier experiments using extracts prepared by sonication (Kelly, 1973), activity was little different in organisms grown on sucrose or thiosulphate. 


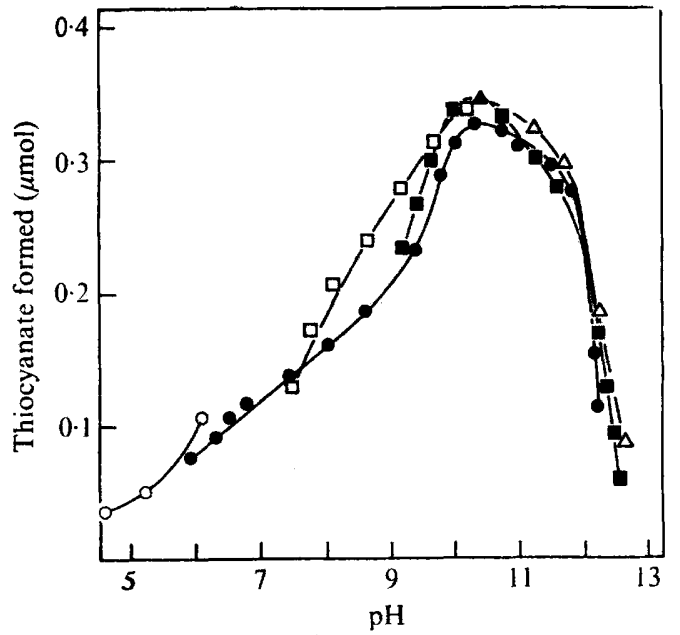

Fig. I

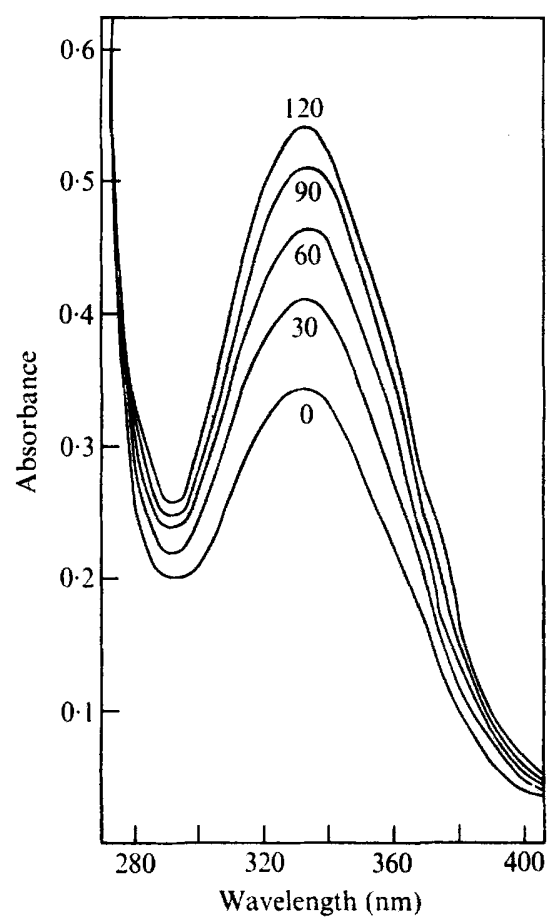

Fig. 2

Fig. I. Effect of $\mathrm{pH}$ on rhodanese. Purified enzyme ( $9.5 \mu \mathrm{g}$ protein per assay) was assayed in the presence of acetate $(O)$, phosphate $(\Theta)$, Tris $/ \mathrm{HCl}(\square)$, Tris $(\Delta)$, Tris/NaOH $(\Delta)$ and glycine/ $\mathrm{NaOH}(\boldsymbol{\square})$ buffers.

Fig. 2. Absorption spectra of a reaction mixture containing dihydrolipoate (and thiosulphate) as substrate for purified rhodanese $(9.5 \mu \mathrm{g}$ protein per assay) after incubation for $0,30,60,90$ and $120 \mathrm{~min}$. The irregularity at 370 to $375 \mathrm{~nm}$ was due to automatic lamp switching by the spectrophotometer and was not a feature of the spectra of $\alpha$-lipoate or lipoamide.
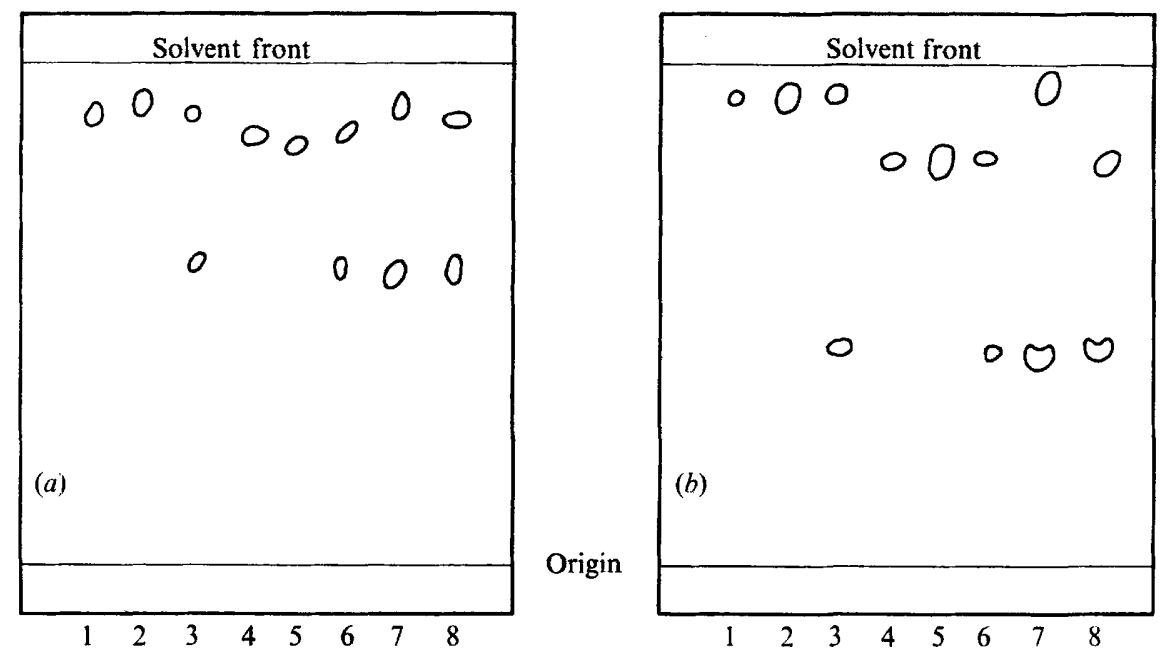

Fig. 3. Thin-layer chromatograms run with (a) solvent 7 and (b) solvent 8: (1) $\alpha$-lipoate; (2) dihydrolipoate; (3) dihydrolipoate persulphide; (4) lipoamide; (5) dihydrolipoamide; (6) dihydrolipoamide persulphide; (7) reaction mixture after $2 \mathrm{~h}$ incubation with dihydrolipoate as substrate; (8) reaction mixture after $2 \mathrm{~h}$ incubation with dihydrolipoamide as substrate. 
Usually the $\mathrm{pH}$ optima for rhodanese enzymes are at least $2 \mathrm{pH}$ units higher than the pH favourable for growth (Tabita et al., 1969; Kelly \& Tuovinen, 1975). In crude extracts of Thiobacillus A2, rhodanese activity was maximal at $\mathrm{pH}$ II.2 (Kelly \& Tuovinen, 1975), but the results of this investigation show that the purified rhodanese was most active at $\mathrm{pH}$ I0.2 to 10.4 . Taylor \& Hoare (I969) thus measured activity under suboptimal conditions $(\mathrm{pH} \mathrm{8 \cdot 0)}$.

Kinetic constants for rhodanese from a number of bacteria showed that the affinity for thiosulphate was 20 to 30 times that for cyanide (Kelly \& Tuovinen, 1975). Apparent $K_{\mathrm{m}}$ values for the purified enzyme from Thiobacillus A2 were 0.36 mM-thiosulphate and $17 \mathrm{~mm}$ cyanide. Similar values were determined for Chromatium strain D (Smith \& Lascelles, 1966) and sulphur-grown $T$. ferrooxidans (Tabita et al., 1969).

The high $K_{\mathrm{m}}$ values for cyanide generally reported for rhodanese, considered with the low endogenous levels of cyanide in most bacteria, indicate a mechanism for rhodanese in vivo involving sulphane-sulphur transfer to an acceptor other than cyanide. Tabita et al. (I969) suggested that, like rhodanese from mammalian sources (Volini \& Westley, 1966), dihydrolipoate or a similar compound might serve this function in thiobacilli. Lipoate has been detected in a number of heterotrophic bacteria (Herbert \& Guest, 1975), but no investigation into the presence of this compound in thiobacilli has been undertaken. There is some dispute over the nature of the early intermediates of thiosulphate cleavage by rhodanese: sulphenyl thiosulphate, a trisulphide or a persulphide have all been suggested (Westley, 1973). We have now demonstrated conclusively that rhodanese catalyses thiosulphate cleavage in the presence of dihydrolipoate or dihydrolipoamide as cosubstrates with the formation of their persulphides as intermediates, leading to the spontaneous formation of sulphide and the oxidized cosubstrates. The formation of $\alpha$-lipoate and lipoamide from dihydrolipoate and dihydrolipoamide respectively has been confirmed by nuclear magnetic resonance spectroscopy (Silver, Howarth \& Kelly, 1976). Whether these particular compounds act as cosubstrates in vivo is not yet established, but it seems highly likely that they or similar sulphydryl compounds are involved in thiosulphate scission in thiobacilli. Thiosulphate may be a central intermediate in the oxidation of a variety of inorganic sulphur compounds (Kelly, 1968; Suzuki, 1965). In various thiobacilli it may undergo oxidative condensation or cleavage by rhodanese, but whereas Thiobacillus A2 can oxidize sulphur and sulphide, it cannot metabolize polythionates or thiocyanate (Taylor \& Hoare, 1969; Kelly, 1973; Kelly \& Tuovinen, 1975). Failure to use thiocyanate together with concepts of how thiocyanate is oxidized in other thiobacilli (Kelly, 1968) would indicate that thiocyanate is not a normal intermediate in Thiobacillus A2.

We suggest that in Thiobacillus A2 the initial step in thiosulphate oxidation is a rhodanesecatalysed cleavage to sulphite and an organic persulphide (such as dihydrolipoate persulphide), which may act as a substrate or sulphane-sulphur donor for an enzyme, such as the sulphur-oxidizing enzyme (Suzuki \& Silver, 1966; Silver \& Lundgren, 1968), which can convert it to sulphite. We have detected weak sulphur-oxidizing enzyme activity in the soluble fraction of crude extracts of thiosulphate-grown Thiobacillus A2. Little evidence exists concerning the enzymology and energetics of the further oxidation of sulphur intermediates by Thiobacillus A2. Although APS reductase is present in sucrose- and formategrown organisms (Silver \& Kelly, unpublished) it is virtually absent from organisms grown on thiosulphate (Aleem, 1975; A. M. Charles, personal communication; Silver, unpublished) but sulphite:cytochrome $c$ oxidoreductase is present in organisms grown on thiosulphate, sucrose or formate. 
This work was made possible by a Travel Fellowship from The National Research Council of Canada to M.S., enabling him to take up a position of Visiting Fellow in the

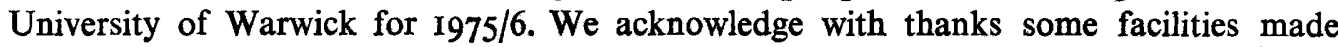
available by the Department of Molecular Sciences. We thank Jill Pothecary for technical assistance.

\section{REFERENCES}

ALEEM, M. I. H. (1975). Biochemical reaction mechanisms in sulfur oxidation by chemosynthetic bacteria. Plant and Soil 43, 189.

Bowen, T. J., Butler, P. J. \& HAProld, F. C. (1965). Some properties of the rhodanese system of Thiobacillus denitrificans. Biochemical Journal 97, 651-657.

Charles, A. M. \& Suzuri, I. (1966). Mechanism of thiosulphate oxidation by Thiobacillus novellus. Biochimica et biophysica acta 128, 510-521.

GuAY, R. \& SILVER, A. M. (1975). Thiobacillus acidophilus sp.nov.; isolation and some physiological characteristics. Canadian Journal of Microbiology 21, 281-285.

HerberT, A. A. \& Guest, J. R. (1975). Lipoic acid content of Escherichia coli and other microorganisms. Archives of Microbiology 106, 259-266.

KeLLY, D. P. (1968). Biochemistry of oxidation of inorganic sulphur compounds by microorganisms. Australian Journal of Science 31, 165-173.

KeLLY, D. P. (1972). Transformation of sulphur and its compounds in soils. (Symposium Internationale sur le Soufre en Agriculture) Annales agronomiques, numéro hors série 1972, $217-232$.

KELLY, D. P. (1973). Inorganic sulphur metabolism in Thiobacillus A2. Ist International Congress for Bacteriology, Abstracts II, 7I. Jerusalem: International Association of Microbiological Societies.

Kelly, D. P. \& Tuovinen, O. H. (1975). Metabolism of inorganic sulphur compounds by Thiobacillus ferrooxidans and some comparative studies on Thiobacillus $\mathrm{A} 2$ and Thiobacillus neapolitanus. Plant and Soil 43, 77-93.

LÉ JohN, H. B., VAN CAESEele, L. \& LeEs, H. (I967). Catabolite repression in the facultative chemoautotroph Thiobacillus novellus. Journal of Bacteriology 94, I484-149I.

LineweAVER, H. \& BURK, D. (1934). The determination of enzyme dissociation constants. Journal of the American Chemical Society 56, 658-666.

Lowry, O. H., Rosebrough, N. J., FarR, A. L. \& Randall, R. J. (195I). Protein measurement with the Folin phenol reagent. Journal of Biological Chemistry 193, 265-275.

NAKAMURA, H. \& TAMURA, Z. (1974). Thin layer chromatography of organic sulfur compounds by the mixed fluorescent method. I. Detection of various classes of compounds. Journal of Chromatography 96, 195-210.

Reed, L. J., KoIKe, M., Levitch, M. E. \& LeACH, F. R. (1958). Studies on the nature and reactions of protein-bound lipoic acid. Journal of Biological Chemistry 232, 143-1 58.

Silver, M. \& Kelly, D. P. (1976). Thin layer chromatography of oxidized and reduced lipoate and lipoamide and their persulphides. Journal of Chromatography 123, 479-48I.

Silver, M. \& LUNDGREN, D. G. (I968). Sulfur-oxidizing enzyme of Ferrobacillus ferrooxidans (Thiobacillus ferrooxidans). Canadian Journal of Biochemistry 46, 457-46r.

Silver, M., HowarTh, O. W. \& KELLY, D. P. (1976). Rhodanese from Thiobacillus A2: determination of activity by proton nuclear magnetic resonance spectroscopy. Journal of General Microbiology 97 , 285-288.

SMith, A. J. \& LASCElles, J. (1966). Thiosulphate metabolism and rhodanese in Chromatium sp. strain D. Journal of General Microbiology 42, 357-370.

SörBo, B. (1975). Thiosulfate sulfurtransferase and mercaptopyruvate sulfurtransferase. In Metabolic Pathways, 3rd edn, vol. 7, pp. 433-456. Edited by D. M. Greenberg. New York and London: Academic Press.

SUZUKI, I. (1965). Oxidation of elemental sulfur by an enzyme system of Thiobacillus thiooxidans. Biochimica et biophysica acta 104, 359-371.

SuzUKI, I. (I975). Mechanisms of inorganic oxidation and energy coupling. Annual Review of Microbiology 28, 85-101.

SuzUKI, I. \& SILVER, M. (1966). The initial product and properties of the sulfur-oxidizing enzyme of thiobacilli. Biochimica et biophysica acta 122, 22-33.

TABita, R., Silver, M. \& LundGRen, D. G. (1969). The rhodanese enzyme of Ferrobacillus ferrooxidans (Thiobacillus ferrooxidans). Canadian Journal of Biochemistry 47, II4I-I 145.

TAYLOR, B. F. \& HOARE, D. S. (1969). New facultative Thiobacillus and a reevaluation of the heterotrophic potential of Thiobacillus novellus. Journal of Bacteriology 100, 487-497.

Villarejo, M. \& Westley, J. (1963). Mechanism of rhodanese catalysis of thiosulfate-lipoate oxidationreduction. Journal of Biological Chemistry 238, 4016-4020. 
VolinI, M. \& WESTLEY, J. (1966). The mechanism of the rhodanese-catalyzed thiosulfate-lipoate reactions. Journal of Biological Chemistry 241, 5168-5176.

WeStLEY, J. (I973). Rhodanese. Advances in Enzymology 39, 327-367.

YoCH, D. C. \& LINDSTROM, E. S. (1971). Survey of the photosynthetic bacteria for rhodanese (thiosulfate: cyanide sulfurtransferase) activity. Journal of Bacteriology ro6, 700-701. 